Титок В. В., к.е.н., доцент

Київський національний університет

будівництва і архітектури

м. Київ, Украӥна

DOI: https://doi.org/10.30525/978-9934-26-145-9-18

\title{
ВИКОРИСТАННЯ МАРКЕТИНГОВИХ КОНЦЕПЦЙ У РАМКАХ ДЕРЖАВНОЇ ПРОГРАМИ «ДОСТУПНЕ ЖИТЛО»
}

Підвищення доступності житла в країні $\epsilon$ головною макроекономічною метою державного регулювання у сфері житлового будівництва, а реалізація й планування програм зведення доступного житла є одним із важливих, але не єдиним засобом досягнення такої мети.

У сучасних умовах ринку лише невелика частина населення має можливість придбати житло самостійно або за допомогою позикових коштів, однак навіть обмежений платоспроможний попит перевищує пропозицію на ринку житла. У зв’язку з цим саме державне регулювання має подолати дисбаланс на ринку і дати можливість поліпшити житлові умови більш широким верствам населення. При цьому не слід забувати про важливість врахування ринкових трендів, де дійовими ланками є споживачі i продавці нерухомості. Тому саме маркетинг, як сучасна бізнес-модель, орієнтована на ринкові потреби, повинна стати сполучною ланкою між державними органами влади та суб'єктами ринкових відносин на шляху реалізації існуючих проблем забезпечення житлом населення.

Можливість придбати житло має лише невелика частина населення, 3 огляду на дорожнечу покупки та інші не менш значущі чинники. Придбання квартири за власні кошти у великому місті досі недосяжна мета для більшості українців: для покупки у великому місті однокімнатної квартири середньостатистичний житель країни, який розраховує тільки на власну зарплату, повинен збирати гроші протягом як мінімум 
6 років у столиці, як максимум 14 років в Одеській області. Аналіз також показав, що для працівників освіти потрібно збирати гроші 36 років, закладів культури - 69 років, охорони здоров'я - 260 років [1].

При цьому частка громадян, які потребують поліпшення житлових умов, неухильно зростає 3 кожним роком. Тому необхідність впровадження механізму державної підтримки ринку нерухомості стає все більш очевидним.

Чинні державні цільові програми будівництва доступного житла фактично стимулюють розвиток будівельної індустрії лише за рахунок пільгового іпотечного житлового кредиту, сплати державою частини вартості житла, що купується, або впровадження системи житлових будівельних заощаджень громадян на покупку житла. У той же час у галузі існує ряд проблем, вирішення яких вимагає більш комплексного підходу в модернізації не тільки технологічної або правової бази, а й загального підходу до здійснення господарської діяльності (бізнес-ідеї), основою якого може стати маркетингова орієнтація проєкту.

Завдання маркетингу в рамках інвестиційно-будівельної діяльності полягає не тільки в досягненні короткострокових цілей (реалізація окремого проєкту), але й у пошуку нових ринкових можливостей i перспектив розвитку підприємств. Тим самим девелопер формує стратегічну основу для реалізації майбутніх проєктів і механізмів активного впливу на ринок нерухомості регіону з урахуванням чинних трендів.

Сьогодні попит на доступне житло в усьому світі залишається високим. Зношеність комунальної інфраструктури, житлового фонду, а також стан економіки України - фактори, вплив яких знаходить відображення на ситуації 3 доступністю житла. У теперішніх умовах розв'язанню питань естетики житла, функціональності, оригінальності взаємодії фасаду та інтер'єру, якісній розробці зовнішнього вигляду і планувального рішення не приділяється належної уваги. Світовий досвід і досвід найближчих країн Європи, як об'єкт ретельного аналізу, може 
стати парадигмою для українських архітекторів у проєктуванні не тільки доступного за ціною категорії житла, але й такого, що відповідає всім сучасним вимогам до таких об'єктів. Наведені міркування відповідають Концепції державної політики по досягненню цілі 10.4. «Українці мають комфортне та доступне житло» [2] і поступово впроваджуються в свідомість девелопера i споживача.

У рамках реалізації державної програми «Доступне житло» держава виконує лише регулюючу і стимулюючу функції для формування умов усунення вищевказаних проблем. Основними ж учасниками програми повинні стати споживачі і девелопери, які реалізують проєкти в галузі будівництва. Саме маркетингова орієнтація останніх повинна стати ключовою ланкою: 3 одного боку - для досягнення комерційних цілей і ефективної реалізації проєкту $з$ урахуванням споживчих переваг, 3 іншого - для вирішення житлової проблеми населення і поновлення ринку нерухомості. Державна програма покликана зробити умови ринку більш привабливими для всіх учасників ринку, знизити економічні ризики i, як наслідок, ціни на житло. Таким чином, можна говорити про те, що в рамках програми «Доступне житло» держава прагне максимально переорієнтувати пропозицію з боку девелоперів на ринкові і соціальні потреби.

Після аналізування структуру взаємодії між різними суб'єктами ринку, можна зробити висновок про те, що система реалізації проєкту повинна бути відкритою для всіх бажаючих вступити в неї i максимально орієнтована на потреби i можливості населення. Саме маркетингова концепція повинна стати ключовою ланкою для реалізації поставлених цілей i вирішення житлових проблем. Шляхи вирішення проблем ринку нерухомості з використання маркетингової концепції в рамках державної програми: розробка девелоперських проєктів 3 урахуванням потреб ринку і можливостей залучення ресурсів державних органів влади; сумісна розробка програм кредитування населення і девелоперів - маркетинг взаємовідносин; маркетингова орієнтація девелопера на найбільш затребувані 
сегменти ринку; сумісна розробка плану розвитку міста 3 урахуванням інтересів девелоперів і потреб адміністрації в забезпеченні житлом населення по різним програмам.

Застосування маркетингового підходу в девелоперських проєктах зустрічається досить рідко через низьку орієнтацію регіональних девелоперів на споживачів і високий попит на ринку нерухомості, що виключає необхідність додаткових витрат на маркетинг. Сьогодні у девелоперів 3'являється необхідність комплексного аналізу девелоперського проєкту не тільки 3 технічної та економічної точок зору, але й з ринкового боку потенційних покупців.

Bce більший інтерес девелопери проявляють до маркетингових досліджень ринку, на підставі яких шикуються гіпотези щодо майбутніх перспектив проєкту та тенденцій розвитку ринку. Основними джерелами інформації служать звіти або замовні дослідження найбільших ріелторських агентств регіону. Більшість девелоперів не надавали особливого значення квартирографії, покупець погоджувався практично на будь-який варіант квартири. У той же час відбулися зміни в споживчих перевагах зміщення інтересу в бік невеликих квартир. Зводити будинки 3 малометражних житлом менш вигідно для забудовника. Це передбачає додаткові витрати на зведення стін, а також на підведення комунікацій до квартир. Але, з огляду на зростаючий попит, девелопери стали все частіше виводити на ринок проєкти, що включають квартири невеликих розмірів. За даними консалтингових агентств, поява такого житла пов'язано з тим, що останнім часом найбільш затребуваними $є$ квартири 3 малим бюджетом покупки в сегменті економ- і середнього класу [3]. Крім того, зважаючи на відносно невисоку вартість, покупці можуть скористатися державною підтримкою або іпотекою при придбанні даного типу квартири.

Розглядаючи можливості реалізації державної програми «Доступне житло», а також застосування маркетингових концепцій в рамках реалізації даної програми усіма учасниками ринку, по-перше, необхідне впровадження відкритих інформаційних 
систем у рамках співпраці між органами влади та будівельними компаніями в цілях контролю над виконанням зобов'язань, а також швидкого реагування на можливості, що відкриваються ринку. По-друге, потрібне удосконалення правової бази, зниження адміністративних бар'єрів і припинення корупційних схем взаємодії $є$ найменш витратними напрямками реалізації проєкту, але в той же час можуть мати значний вплив на сферу нерухомості та вирішення житлових проблем населення.

\section{Література:}

1. Титок В.В. Доступність житла для населення: методичні аспекти та інституційні чинники. Шляхи підвищення ефективності будівнищтва в умовах формування ринкових відносин. 2018. № 38. С. 147-161.

2. Пріоритети уряду 2019-2020 роки щодо реформування місцевого самоврядування. URL: http://www.slg-coe.org.ua/wp-content/uploads/2019/11/ VyacheslavNEHODA_Panel1_.pdf (дата звернення: 06.10.2021).

3. Скільки коштує однокімнатна квартира в Києві URL: https://thecapital.com.ua/uk/skolko-stoit-odnokomnatnaya-kvartira-v-kieve/ (дата звернення: 06.10.2021). 